\title{
Public procurement and corruption during Covid-19: self-monitoring and whistleblowing incentives after Srebrena Malina
}

\begin{abstract}
Crises and emergencies tend to increase opportunities for corruption in public procurement. This article shows how the Covid-19 pandemic has given rise to new corruption opportunities and how regulators are trying to combat these, using the example of the case of the Bosnian raspberry firm Srebrena Malina. The literature review concludes that prevention mechanisms focus on the legal and regulatory aspects without considering firms' perspectives. In contrast, an approach based on summary content analysis may help firms develop potential selfmonitoring solutions that they can apply to ensure compliance with anti-corruption regulations and avoid sanctions. Explorative expert interviews with ten international compliance experts are also conducted. The findings illustrate that whistleblowing incentives could foster compliance with existing regulations and policies in public procurement. This article advocates a more consequential implementation of the current anti-corruption and public procurement regulations alongside self-monitoring measures in the form of whistleblowing incentives.
\end{abstract}

Keywords: Covid-19, public procurement, emergency procurement, purchasing, corruption, Bosnia and Herzegovina, Srebrena Malina, medical equipment, PPE

Introduction

Within the past 100 years, since in fact the influenza epidemic, no public health event has affected the world as much as the current Covid-19 pandemic. Aside of threatening the health and well-being of the entire global population, Covid-19 has also had immense adverse societal and economic effects, causing major supply chain disruptions (van Hoek 2020) and giving rise to new opportunities for corruption in public procurement. Corruption, defined as the abuse of public office for private gain (Teichmann 2017), is an issue that affects every country on earth. The costs of corruption are high and they can have devastating effects on the public sector. Simultaneously the costs of corruption inflict risks on private businesses and may harm private citizens (Teichmann and Sergi 2018). When it comes to the former, Bellavite Pellegrini et al. (2015) find that country corruption indexes correlate negatively with the total annual return on the shares of industrial companies.

The potential risks for corruption and organised crime often increase during crises as emergency measures are implemented. For example, the Covid-19 pandemic has shed light on the shortcomings of public-private healthcare procurement systems which have seen several cases of non-compliant tenders for personal protective 
equipment (PPE) and ventilators. While all efforts are devoted to combating the pandemic, shortcuts in public procurement have been taken, defective medical equipment has been sold and petty corruption has been rising.

One prominent corruption case arising during the pandemic was made public in the western Balkan state of Bosnia and Herzegovina (BiH). A firm whose business lay in the processing of raspberries, Srebrena Malina ('Silver Raspberry'), procured 100 ventilators from China without having any experience in the medical field or, initially, having obtained a licence to trade medical equipment.

This article discusses how emergencies can increase opportunities for, and the risks of, corruption in public procurement as exemplified by the scandal surrounding Srebrena Malina. The study is highly relevant to current events because the Covid-19 pandemic has had adverse effects on nearly all areas of life, the economy and public procurement. The severely adverse impacts of corruption, which many countries experience, have increased significantly since the outbreak of the pandemic. Therefore cases of corruption related to Covid-19 must receive public attention so that further economic losses and human casualties can be avoided.

Our literature review in the next section discusses perspectives on corruption and risk in public procurement, illustrating the corruption issues which have arisen out of the pandemic. Using the Srebrena Malina case as an example, we show how emergency situations declared by governments increase the risk of corruption in public procurement. Because most of the literature is focused on the preventive perspective in the fight against corruption in public procurement, this study investigates why eliminating corruption is desirable from a company perspective and the direction in which anti-corruption measures can be taken within companies, thus contributing to the closing of a research gap. Anti-corruption measures in terms of self-monitoring and whistleblowing incentives are suggested based on a qualitative study of ten interviews with international compliance and forensic experts and researchers. In contrast to other studies that focus mainly on the regulatory implications of corruption in public procurement, this study recommends the measures that may be applied by companies which have been engaged in corrupt activities as a means of facilitating a change in internal company culture and avoiding tough sanctions.

\section{Literature review}

\section{Corruption and risks in public procurement}

Public procurement contracts help with the efficient budgeting of funds and boost free market competition. Government procurement markets in post-transition countries, such as Bosnia and Herzegovina, contribute a significant share of the national economy and their importance seems to rise in times of economic crisis (Slijepčević et al. 2015). Independently of the level of development, political inclination and geographical location, public procurement is an integral part of any country's economy. According to estimates, the value of public procurement corresponds to 15 per cent of world GDP (Bajari and Lewis 2009). Kähkönen and Lintukangas (2013) find that supply management and purchasing play an essential part in companies' value creation and also affect both their success and their performance. 
Within the EU, public procurement procedures follow five fundamental principles: non-discrimination; equal treatment; transparency; proportionality; and mutual recognition. Similar principles are also valid in non-EU countries (Lindskog et al. 2010). One crucial step in any tendering process is finding the best bid. EU Directives 2004/17/EC and 2004/18/EC specify, in Articles 55 and 53, that the tender must specify how bids will be evaluated regarding the method of supplier selection, giving little room for discretion and reducing the risk of discrimination (Bergman and Lundberg 2013). EU supplier selection methods frequently combine price and quality into a total score (Verdeaux 2003). In contrast in the United States (US), procurement contracts are usually awarded to the lowest qualified bidder (Potoski 2008). Using both price and quality as criteria in supplier selection might add complexity to the procedure but increase the efficiency of public procurement. The design and quality of the procured product often depend on the buyer's choice of award criteria. When a single award criterion combines price and quality, this encompasses the scoring of bids on both these measures with a overall ranking. Scores are calculated based on a bid evaluation formula with inputs based on price and quality and the respective weights which are attached to each (Stilger et al. 2017).

Buyers usually intend to optimise quality while minimising cost, so public procurement can be quite complex (Bergman and Lundberg 2013) and many supplier selection methods used in practice are, as a consequence, rather poorly designed. To achieve an optimal combination of low prices and high quality, low transaction costs, competitive bidding and an absence of favouritism and corruption are required.

Efficiency in public procurement ensures that public bodies obtain the best value for their money. One crucial factor that influences the efficiency of public procurement is transparency. When procurement procedures are discretionary and opaque, firms have fewer incentives to enter a market. This can also be seen when firms obtain 'preferred status' via the bribing of public officials (Evenett and Hoekman 2005).

Bals et al. (2019) argue that purchasing and supply management professionals must have procurement-specific and generic management competencies. New competency requirements revolve mainly around innovation, digitisation and sustainability. When employees are trained in developing and applying such competencies, performance can be sustained over time, even under rapidly changing contextual factors (Bals et al. 2019), which could be highly relevant when dealing with an emergency situation.

Public procurement currently faces competing priorities, including the advance of environmental protection, the promotion of innovation, cost efficiency and legal conformity (Patrucco et al. 2017). The risks of public procurement generally include the involvement of high-level authorities in decision-making; the abusive use of uncompetitive procedures invoking the existence of legal exceptions; revealing confidential information to candidates; deviations from the correct bid opening procedure; frequent and unjustified meetings with the contracting party; the misuse of extreme emergency cases; and many more (Manea and Popa 2010).

Corruption in public procurement can occur during the pre- and post-tender stages (Slijepčević et al. 2015). Problem indicators pointed out within the media are 
frequent tender cancellations, project delays and other issues arising from the malfunctioning of procurement procedures. In addition, non-governmental organisations (NGOs), the media and financial audit bodies have reported numerous problems relating to the timeliness of procuring necessary services and goods (European Court of Editors 2018). The economic and social consequences of delays in public procurement are significant - they jeopardise the healthcare system, the safety of citizens and military security and assistance to civilians, while leading also to unjustified costs (European Court of Editors 2018).

Focusing on corruption in public procurement in Africa, Appolloni and Mushagalusa Nshombo (2014) find that common procurement-related forms of corruption are embezzlement and fraud favouritism, extortion and bribery. They argue that efforts at minimising public procurement corruption must target the challenges at both the central and the local government levels that are perpetuating the problem. According to Appolloni and Mushagalusa Nshombo (2014), the determinants of corruption in African countries' public procurement are political commitment, social factors, organisational factors and economic factors. Moreover, non-compliant behaviour in the purchasing process can arise when many individuals carry out the purchase of goods and services within an organisation rather than a purchasing department, leading to a scattering of responsibilities (Karjalainen et al. 2009).

The legal framework around public procurement is supposed to prevent irrational favouring such as bribes and to guarantee fair treatment. However, to avoid 'friendly' corruption and nepotism, many firms change their suppliers every few years and set up rules for gift-taking (Lindskog et al. 2010). Kauppi and van Raaj (2015) use agency theory to analyse non-compliance with centrally-negotiated framework agreements in governmental agencies. They find that government employees' noncompliance can be reduced via guidance and training whereas output monitoring does not reduce non-compliance. The underlying reason is that both principals and agents may have information of which the other party is unaware (Kauppi and van Raaj 2015).

\section{Emergency procurement}

To prepare for, mitigate, respond to and recover from disasters, emergency supply management is required. This policy sub-system requires intergovernmental, multi-phased efforts (Donahue and Joyce 2001). In emergency procurement, corruption lowers the quality of services and products provided, reduces resources for lifesaving operations and diverts aid from those in need. Crises generally turn out to be more amenable to corruption because funding levels can increase significantly, there are reduced financial controls and staff can change frequently (Cremer 2000). Moreover public support for humanitarian aid abroad and in the affected country can be affected by corruption within emergency procurement arrangements (Schultz and Søreide 2008).

The largest share of emergency budgets is frequently reserved for supply management, i.e. the purchase of goods and services. At the same time, this process is considered the most vulnerable to corruption. Corrupt activities such as incentive payments can add additional costs to contract bids (Schultz and Søreide 2008). As- 
suming that 30 per cent of aid money is spent on procurement, a 10 per cent increase in incentive payments would imply potential losses of millions of dollars (International Group for Anti-Corruption Coordination 2005).

Factors that increase opportunities for corruption in an emergency procurement situation include high levels of discretion; the fast tracking of financial control procedures and ad hoc acquisitions; increased demand for emergency supplies, which lets prices soar and makes it harder to detect bribery; pressure to spend donations quickly, which could prompt aid agencies and donors to favour larger contracts over many smaller ones (the bigger the contract, the more willing a firm will usually be to take the risk of corruption); whether corruption is a significant issue in the country (even in the absence of emergency); alongside several others (Schultz and Søreide 2008). Traditional anti-corruption tools include ethical codes, legal instruments and other vehicles (Csáki and Gelléri 2006). Among other approaches, Søreide (2002) lists the benchmarking of prices, the development of rules for exceptional cases, the disruption of potentially corrupt relationships via the simplification of rules and clauses on the disqualification of bidders as strategies which may help to reduce opportunities for corruption in public procurement.

\section{Corruption during the Covid-19 pandemic and regulatory approaches}

The Covid-19 pandemic has confirmed that emergency situations increase the risks of corruption in public procurement and should thus be appropriately prepared for. In this context, supply chains are being confronted with unprecedented challenges. With Covid-19, public procurement in particular has taken on a 'crucial role in crisis management' (Knight et al. 2020: 7) since medical supplies, PPE and ventilators must be acquired urgently. The Covid-19 pandemic has, at the same time, created increased opportunities for corruption due to its complexity and since large government contracts have been given to companies without competitive tenders or adherence to proper due diligence procedures. Therefore the pandemic has several implications for emergency preparedness planning, especially in that governments must, as a priority, establish emergency (and within date) stockpiles of critical safety and health consumables and medical equipment (Knight et al. 2020).

According to Steingrüber et al. (2020) responses to Covid-19 have been subject to breaches of anti-corruption standards such as 'cutting corners in procurement processes' or those who are in power profiting unjustly from the crisis to increase their own wealth. During an outbreak as severe as the Covid-19 pandemic:

$[\ldots]$ it is tempting to deprioritize the mitigation and management of corruption risks and upholding sanctions against perpetrators of corruption. (Steingrüber et al. 2020: 1)

Many countries require financial assistance to mitigate systemic weaknesses and tackle Covid-19. Anti-corruption protocols must be applied here to ensure that forms of assistance deployed to fight the pandemic reach those who need it (Steingrüber et al. 2020).

According to the United Nations Office on Drugs and Crime (UNODC), restrictions on movement related to Covid-19 have motivated the trafficking of falsified 
and sub-standard medical products. As reported by the World Customs Organization and by Interpol, an increase in the seizure of falsified and sub-standard medical products first occurred in March 2020. The UNODC argues that the rise in the trafficking of said equipment:

[...] signals a significant shift in organized criminal group behaviour that is directly attributable to the COVID-19 pandemic [...]. (UNODC 2020: 7)

UNODC further suggests that, in the foreseeable future, criminal efforts are likely to shift from the trafficking of personal protective equipment towards the delivery of vaccines and cyberattacks on critical infrastructure in the form of online scams aimed at health procurement authorities. Any existing weaknesses in regulatory and legal frameworks have been magnified by the pandemic, making it difficult to find immediate, short-term solutions (UNODC 2020).

Vecchi and Cusumano (2020: 1) find that the pandemic in Italy has:

Thrown into sharp focus the shortcoming of public-private healthcare procurement systems...

However, the crisis has also offered opportunities to reshape systems for future emergencies. In particular, the pandemic has cast light on Italy's lack of preparation and coordination and its top-down cost-cutting approach toward the centralisation of procurement. Prices of pharmaceutical products, technology and medical devices have risen above the level of general inflation for years meaning that, in many nations, public healthcare budgets had been under stress even before the pandemic (Vecchi and Cusumano 2020).

Simon and Aalbers (2020) assess Latin America's ability to detect, punish and prevent corruption during Covid-19 within the scope of the 2020 Capacity to Combat Corruption (CCC) Index. According to the report, the pandemic has led to an 'environment of emergency spending' (Simon and Aalbers 2020: 1). The result has been that the risk of the mismanagement of funds and corruption has increased as governments struggle to acquire medical equipment and mitigate the economic fallout.

Some prominent cases of corruption related to Covid-19 include Serbia's president, Aleksandar Vučić, claiming that he had been forced to buy ventilators on the semi-grey market due to a lack of availability on the European market. In response to allegations concerning the integrity of the procurement procedure, Vučić was quoted as saying:

You can prosecute me one day for providing respirators to the people (quoted in Simić 2020).

In Italy, an agricultural company won a contract to supply face masks to the government which led to an investigation of the public procurement agency (Giuletti and Menafra 2020). It has further been reported that Norwegian doctors have been breaking medicines agency guidelines to supply prescriptions to family and friends (Steingrüber et al. 2020). In Russia, oligarchs have managed to purchase scarce ventilators 
and recruit on-call doctors to turn their homes into makeshift clinics to ensure they can avoid seeking treatment at overcrowded hospitals (Sauer et al. 2020). According to OECD estimates, up to $\$ 2$ trillion in procurement costs could be lost to corruption because of the pandemic (Clarke et al. 2020).

In response to the pandemic and the resulting need for medical supplies and PPE to be purchased by public authorities, the European Commission published new guidance for public buyers intending to:

[...] help public authorities use the flexibility provided by the EU's public procurement framework to ensure rapid and efficient purchases of all necessary equipment. (European Commission 2020)

The new guidelines allow for a shortening of the public procurement process and for emergency procurement, the latter not being subject to EU procedural requirements and not requiring a prior publication of tender notices. Moreover the guidance encourages public buyers to consider alternative innovative solutions and options for engaging with the market (2020/C $108 \mathrm{I} / 01)$.

To tackle corruption during emergencies such as the Covid-19 pandemic, the United Nations Development Programme (UNDP) identifies a risk-based prioritisation framework to be a crucial first step. This framework would determine accountability, governance and transparency mechanisms that must be integrated into Covid-19 public health response planning and design (Clarke et al. 2020). For countries to be sufficiently prepared for any emergency, institutions must operate effectively. The UNDP argues that a multi-sectoral and multi-stakeholder oversight body, involving academia, civil society, governments and anti-corruption audit and oversight institutions, would help raise awareness and promote dialogue between the anti-corruption and healthcare communities (Clarke et al. 2020). In addition, the UNDP details that community-led monitoring mechanisms will rely on public bottom-up social accountability to achieve a robust response. There must, consequently, be avenues for citizens to report corruption (Clarke et al. 2020).

On 15 April 2020, the Council of Europe's Group of States against Corruption (GRECO) published guidelines addressed to its 50 member states to prevent corruption in the context of the pandemic. The guidelines were issued by GRECO president Marin Mrčela who stressed that the pandemic increased corruption risks, especially in the health sector, due to surges in the urgent need for medical equipment and the simplification of procurement regulations alongside overburdened medical staff and overcrowded medical facilities (Mrčela 2020). Furthermore, Mrčela emphasised that any decisions made by central, regional and local authorities in the face of the pandemic must be transparent and subject to oversight and accountability. Furthermore, even in times of crisis, standards and values such as accountability and transparency should not be compromised and that digital transparency portals may serve as a valuable anti-corruption tool and instrument to protect the rule of law.

In its report on 'connecting the business and human rights and anti-corruption agendas', the UN Working Group on Business and Human Rights argued that bribery could divert medicines, leading to the deaths of people deprived of treatment $(\mathrm{Hu}-$ 
man Rights Council 2020). The report urged governments to implement more robust policy and legal measures such as reforming beneficial ownership laws to strengthen transparency and prevent corruption. Moreover the report demanded that individuals engaging in corruption or human rights abuses should be reprimanded via targeted sanctions such as asset freezes and visa bans.

Marquette (2020) stresses that, instead of not doing the right things because they take too long, governments must find ways to do the right things quickly. Moreover Steingrüber et al. (2020) argue that traditional corruption prevention mechanisms are not able to respond to the pandemic, as experience of the Ebola outbreak has previously demonstrated. They argue that, instead, anti-corruption policies should be built into sector-based intervention design. Drug research and development should be strictly regulated and decision-making should be kept under scrutiny to secure equal access. Public interest and donor organisations should direct funding via existing channels that already apply anti-corruption best practices in the area of health (Steingrüber et al. 2020).

Experts also point out that civil society must be involved in monitoring procurement systems and health outcomes and that budget spending must be tracked and user feedback provided. In developing countries in particular, according to Steingrüber et al. (2020), health workforce governance, management and recruitment have failed due to a lack of transparency and corruption. Therefore, it is also vital to keep involving civil society in monitoring health outcomes and procurement systems to provide feedback and to track budget spending. In addition, practitioners must ensure integrity in the health sector by understanding the social forces that perpetuate corrupt practices (Steingrüber et al. 2020).

\section{The Srebrena Malina case}

As an example of how emergencies give rise to increased opportunities for corruption in public procurement, we turn the discussion to the case of Srebrena Malina. Information about this case, as well as on corruption and organised crime connected with the Covid-19 pandemic, was gathered in the first place via an online search of both peer-reviewed literature and media reports. Unfortunately - but understandably given the short time lag - there is a lack of peer-reviewed scholarly perspectives and sources of empirical data about the connections between Covid-19 and corruption/ organised crime concerning Srebrena Malina. Therefore, the review of literature here relies heavily on international media reports and online English, German and Italian sources the accuracy of which was ensured via a comparison of reports from various outlets.

In May 2020, a criminal inquiry was established into the import of defective ventilators for Covid-19 patients in $\mathrm{BiH}$. The ventilators had been procured by the civil protection authority (FUCZ) and imported from China. FUCZ had recruited raspberry processing firm Srebrena Malina, which did not have a licence to import medical equipment, to procure 100 ventilators for 10.5 million Bosnian marks ( $€ 5.3$ million) from China. The necessary permit was only obtained by Srebrena Malina after eighty out of the 100 ventilators had already arrived, equipment which had not been recommended or approved by any medical experts. Due to the Covid-19 pandemic, the $\mathrm{BiH}$ 
government had relaxed public procurement requirements to facilitate medical equipment purchases through direct bargaining with suppliers instead of public tender ( $\mathrm{Zu}$ vela et al. 2020). The $\mathrm{BiH}$ media reported the scheme in April 2020, prompting a public uproar and culminating in the launch of the criminal inquiry (Ljubas 2020). The senior official in charge, Fahrudin Solak, head of FUCZ, was suspended but denied any wrongdoing (Zuvela et al. 2020). Alongside Solak, another main suspect is the prime minister of the Federation of $\mathrm{BiH}$ entity government, Fadil Novalić (Cuckić 2020b).

The investigation intends to discover why Srebrena Malina was selected over other companies with experience in procuring medical equipment and who could have imported cheaper ventilators. Srebrena Malina paid more than $€ 45,000$ for each ventilator - much more than such equipment usually costs. According to the prosecutor's office, neither do the imported ventilators - which provide only basic breathing support - meet minimum criteria for the adequate treatment of the complex issues raised by Covid-19 patients with breathing difficulties and should not be used in intensive care units (Zuvela et al. 2020). It has also been revealed that the unsuitability of the machines in a Covid-19 context was made public, albeit to the Shanghai stock exchange, by their manufacturer three weeks prior to the purchase and a month before they were received (Pekmez and Husaric 2021).

Srebrena Malina is co-owned by television presenter Fikret Hodžić, also one of the prime suspects in the case, and cultivates a close relationship with the Party of Democratic Action (SDA; the largest Bosniak political party) of which Prime Minister Novalić is a member (Cuckić 2020b; Zuvela et al. 2020).

All three suspects were arrested for alleged money laundering, abuse of office, forgery, the destruction of business documents and trade books associated with the commission of a criminal offence and receiving rewards for trading, but were released shortly after even though the prosecution had demanded one month detentions. The public prosecutor, Džermin Pasić, filed an appeal against this court decision (Cuckić 2020b; Ljubas 2020). According to Pasić, the investigation revealed that Hodžić and the prime minister had already been in contact before the official offer for ventilators was submitted to the government; and that the government had promised payment to the Chinese manufacturer before the contract had even been concluded. Moreover the delivered ventilators were not the ones initially referred to in the contract; and both the offer and contract were changed after they had been signed (Cuckić 2020b).

In response to the scandal, the executive director of Transparency International Bosnia and Herzegovina, Ivana Korajlić, argued that her organisation had warned from the beginning that this, and other, cases represented abuses of the exceptions to the application of the law (quoted in Cuckić 2020b). The FBiH finance minister, Jelka Miličević, also commented that the tender seemed suspicious and that the issue should be investigated (N1 Sarajevo 2020).

According to Cuckić (2020b), the BiH justice system and the political lines have become blurred, meaning that those involved in the case are coming under enormous political pressure. In particular, Bakir Izetbegović, the SDA leader, has accused the chief prosecutor Gordana Tadić, who belongs to the Croat community, of basing the 
investigation on ethnicity because Novalić is of Bosniak descent. Eldin Karić, editorin-chief of the anti-corruption portal Žurnal, claims that the SDA - like the other parties - frequently uses populist statements revolving around the endangerment of Bosniaks to protect itself against allegations of crimes (quoted in Cuckić 2020b). The question of whether Srebrena Malina, civil defence administrators or federal officials actually broke the law is complicated by BiH's division of powers and resources between the country's entities and its ethnic-oriented political structure.

\section{Implications}

The Srebrena Malina ventilator affair has been identified as the biggest corruption scandal in the western Balkans since the 'Extortion' affair in North Macedonia during which the chief special prosecutor and anti-corruption advocate, Katica Janeva, was tried for the abuse of authority and for illegal property gains (Cuckić 2020b). The case, however, is not unique. Other $\mathrm{BiH}$ import and export companies close to the political establishment have also been under scrutiny since the beginning of the pandemic as accusations of profiteering have intensified and the authorities have struggled to procure the necessary medical equipment (Zuvela et al. 2020). Previously the state had selected the $\mathrm{BiH}$ tourist agency, Travel for Fun, to supply protective equipment via a $€ 1.4$ million contract. Between 2014 and 2017, the value of public procurement by $\mathrm{BiH}$ institutions was over $€ 220$ million, not including local and entity governments, while public procurement by $\mathrm{BiH}$ institutions amounts to 15 per cent of the annual budget on average.

Corruption and organised crime are two significant obstacles that south-east European societies face (Qerimi and Sergi 2007). Institutional performance can be measured by institutional effectiveness at dismantling or reducing corrupt behaviour (Qerimi and Sergi 2012, 2021). The western Balkans have weak institutions and the countries of the region perform poorly in an economic sense. In addition, self-interest among the elites in power could inhibit the successful implementation of anti-corruption initiatives (Budak and Rajh 2013). The $\mathrm{BiH}$ procurement system has already been identified as a critical corruption zone, not just as a result of the Covid-19 pandemic (Cuckić 2020a).

The first $\mathrm{BiH}$ law on public procurement, which decentralised public procurement by shifting responsibility to contracting authorities and which demanded emphatic transparency for the publication of notices on certain procurements, entered into force on 10 September 2004. It also supplied a way of reviewing complaints. Secondary legislation included procurement guidelines, regulations and standard bidding documents (Duli et al. 2011). In addition, the law established two independent institutions at state level: the Procurement Review Body (accountable to the BiH Assembly); and the Public Procurement Agency (accountable to the BiH Council of Ministers). The law has been amended several times since its implementation. However, according to Duli et al. (2011), out of all the western Balkan countries, the $\mathrm{BiH}$ law on public procurement is the one least aligned with European Commission procurement directives.

$\mathrm{BiH}$ has received over $€ 80$ million in emergency aid to help the country deal with the Covid-19 pandemic as well as shipments of disinfectant and medical supplies 
from the Turkish government and the NATO alliance. In addition, the International Monetary Fund alone approved $€ 311$ million (nearly twice as much as for any other Balkan state) in emergency assistance to help the country balance its payments in the face of Covid-19 (Djugum et al. 2002). However, should these funds and $\mathrm{BiH}$ taxpayer money not reach their intended destinations, or be invested in deficient equipment, the Covid-19 pandemic cannot be mitigated effectively. This will eventually lead to more deaths and higher economic losses.

Ventilators and other medical equipment are highly susceptible to corruption and organised crime because they are scarce and immensely valuable in the context of the pandemic. In addition, they are portable, meaning that shipments can be stolen and sold to wealthy elites. The main issue is that crises create increased opportunities for corrupt behaviour and opportunism in the form, for example, of counterfeit and sub-standard products, illicit online sales of medical supplies and fraud. Thus corruption and organised crime intelligence and analysis must be built into health interventions (Marquette 2020).

Corruption played some sort of role in Srebrena Malina's winning of the government contract allowing it to import medical equipment from China without the necessary licence or expertise. It is unclear, however, how and why Srebrena Malina was selected for the deal and how Solak and Novalić were involved. One potential answer could lie in Hodžić's connection to SDA. More widely the case illustrates the importance of transparency and compliance in public procurement and the healthcare sector. Governments should not allow firms to take shortcuts or approve alternative procurement and tendering procedures even when there are extenuating emergencies. Thus the Srebrena Malina case is an example of the need to advocate for suitable compliance measures which are tailored to the new challenges posed by emergencies such as those arising during the Covid-19 pandemic.

\section{Expert interviews}

\section{Materials and methods}

The literature review illustrates that scholarly perspectives and expert opinions usually focus on the preventive perspective in the fight against corruption in public procurement, i.e. on regulatory measures and policies without considering the organisational factors that facilitate corruption and the perspectives of firms themselves. Therefore, to investigate the issue from a different viewpoint, we conducted expert interviews with ten international compliance experts, forensic services experts and researchers (see Table 1) from a variety of countries including Germany, Hong Kong, India, Switzerland, the United Arab Emirates and the United States. The intention was to find out how firms could foster whistleblowing to encourage self-monitoring. However, this issue, in connection with corruption in (emergency) public procurement, has been so little investigated in the past that no clear hypothesis could be formulated regarding the literature review.

The purpose of this study is to explore the field in a new way and develop innovative theory. Consequently it was determined that expert interviews would be most suitable because these would assist with gaining primary access to previously unex- 
plored research questions. Furthermore, they would facilitate the establishment of new hypotheses and questions which could be tested via mixed methods when it comes to future research (Elo and Kyngäs 2008). Suitable experts were found via purposive sampling based on the study's specific research interest, using an analysis of related scientific publications, corporate websites, newspaper articles and internet searches. Potential interview partners were contacted via email and informed of the research aim. Participants who had specific characteristics in common and were able to provide diverse and relevant data were selected and guaranteed anonymity due to their highly exposed positions. Experts from various locations were interviewed to ensure broad applicability. Corruption is, after all, a worldwide phenomenon that has far-reaching effects especially in times of global emergency. Moreover public procurement frequently involves several jurisdictions, as seen in the Srebrena Malina case as well as in other instances of corruption in emergency procurement related to Covid-19. All interview partners had considerable professional experience and full educational backgrounds.

The interviews intended to gather interpretive knowledge, meaning that subjective points of view could be explored. Interviews were conducted in person, via video chat, as well as via the telephone. In person interviews are normally preferable because interview partners tend to be more comfortable and the interviewer has more control over the interview process (Gläser and Laudel 2010) although Covid-19 has raised major barriers in this. However, the typical limitations of telephone interviews, such as the inability to monitor facial expression, did not represent significant obstacles to this research since our interview partners were asked to make general statements rather than reveal confidential information. Therefore, video interviews via Skype or similar technology were deemed a suitable alternative to in-person and telephone interviews; in addition, they offer the same flexibility as telephone interviews (they can be scheduled at short notice and do not require travel) while nevertheless allowing the interviewer to gather visual information.

\section{Table 1 - Interview partners}

\begin{tabular}{|l|l|l|}
\hline $\begin{array}{l}\text { Interview } \\
\text { partner }\end{array}$ & Job title/role & Company type \\
\hline 1 & Partner, fraud investigation and dispute services & Big four consulting firm \\
\hline 2 & Partner, fraud investigation and dispute services & Big four consulting firm \\
\hline 3 & Partner, fraud investigation and dispute services & Big four consulting firm \\
\hline 4 & Full professor & Business school \\
\hline 5 & Chief compliance officer & Industrial company \\
\hline 6 & Partner, fraud investigation and dispute services & Big four consulting firm \\
\hline 7 & Group compliance officer & Industrial company \\
\hline 8 & Compliance officer & Pharmaceutical company \\
\hline 9 & Compliance officer & Pharmaceutical company \\
\hline
\end{tabular}




\begin{tabular}{|l|l|l|}
\hline $\begin{array}{l}\text { Interview } \\
\text { partner }\end{array}$ & Job title/role & Company type \\
\hline 10 & Assistant professor & Business school \\
\hline
\end{tabular}

Due to the study's explorative nature, interviews were semi-standardised meaning that questions were broadly pre-determined but interviewees had freedom to develop their own response. In addition, a degree of flexibility was supported: the order of the questions was adjusted when necessary and follow-up questions added.

Our interview partners were asked why employees might be hesitant to blow the whistle and how whistleblowing could be incentivised, while the potential risks of whistleblowing were discussed as well. The theoretical saturation point was reached after ten interviews. During the literature review, an understanding of the study's topic was developed, but openness was maintained during the analysis, meaning that no premature conclusions or categorisations were made.

In line with Mayring (2010), qualitative methods were employed to analyse the statements made by our interview partners to facilitate summary content analysis. This was selected as the preferred approach because it helps gain an overview of a broad range of text. In particular qualitative content analysis aims to analyse (fixed) communication themes through a systematic framework (Mayring 2010), identified during a systematic coding and classification process (Hsieh and Shannon 2005).

Interviews were recorded and transcribed as fully as possible, including subtle information like pauses and non-verbal clues, and then exported into MAXQDA qualitative data analysis software. The interviews were then read and relevant statements highlighted before being summarised in accordance with Mayring (2010). During this multistep process, text segments were first selected and then refined via the deletion of fillers and unnecessary pauses. The segments were next translated into an appropriate language and other unnecessary elements eliminated. After that, the statements were paraphrased and reduced to their essential meaning. Lastly, any elements that occurred more than once were deleted. The intention throughout was to derive interview partners' most critical statements, achieved via eliminating irrelevant content with a view to establishing a refined overview of their most important statements.

The next step comprised shifting relevant text segments into categories formed initially during the summarisation process but subsequently amended several times. MAXQDA was used to facilitate this process but was not employed for any other analytical tasks. Text segments could be part of only one category. Selecting categories and deciding which text segments are relevant is naturally a rather subjective task. However, all forms of research include subjective elements (Mayring 2010).

Sample analysis is presented below to demonstrate the significant difference between the initial segments of text and the results of the reduction and summarisation process.

\section{(Interviewee 4)}

Step 1: 'So I think the challenge is that, um... uh... Uh, this is... there's like... I think there is a huge... a huge, um, penalty and, um, stigma associated with being a whistleblower.' 
Step 2: 'So I think the challenge is that there is a huge penalty and stigma associated with being a whistleblower.'

Step 3: 'There is a huge penalty and stigma associated with being a whistleblower.'

Step 4: 'Negative stigma associated with whistleblowing.'

\section{Results}

The interview partners emphasised that corruption continues to be a major problem in many countries and that bribes could be necessary even to gain business in the first place:

And yet $[\ldots]$ there are some countries in the world where there's absolutely no way on earth that you can do business unless you pay bribes. (Interview partner 1)

Interview partner 6 added that some government officials would not grant the necessary permissions or contracts without a bribe. According to interview partner 9 , the underlying reasons for corruption might lie in officials' low salaries and poverty. Furthermore, in the view of interview partner 1, a client who offers significant investment could be accepted without being asked too many questions especially at a time of low turnover. In an emergency situation, compliance procedures are neglected because the particular equipment is needed urgently.

Moreover, our interview partners stressed that, even though most companies have some framework of formal anti-corruption rules, employees are not necessarily prevented from engaging in corrupt behaviour. For example, interview partner 3 explained:

They had all the policies, they had it there, but it was still too much 'check the box'. It wasn't really embedded.

\section{Likewise, interview partner 1 argued:}

I mean, they will say they don't want to do it at the very top level. But then some of these organisations are so huge.

In some cases, according to interview partner 6 , a lack of compliance with formal anti-corruption rules can be attributed to a lack of awareness. When there is an unclear code of conduct and a lack of training, companies could find themselves in trouble. As interview partner 3 stressed, it does not help that many employees view corruption as a 'victimless crime' with codes of ethics having little impact on such a culture; and that some employees might even believe they are doing the company a favour when engaging in corruption to secure a government contract.

One common tool that companies use to ensure compliance with legal anti-corruption requirements is whistleblowing. However, whistleblowing can have adverse effects on a person's career and lead to social exclusion in the workplace. For instance, interview partner 1 recounted how they had been laid off for blowing the whistle. Consequently many employees who have blown the whistle once are unlike- 
ly to do it again because of their negative past experiences. Interview partner 4 summarised it thus:

There can be no good outcome for you. You're going to get fired if you don't say anything and if you do say something, you're going to be either treated like a pariah or be demoted or fired, unable to get a job in the industry.

In addition, companies may be inclined to protect high-profile employees rather than the person blowing the whistle:

The initial response will not be to believe the whistleblower but to protect the individual because it is probably a high-profile person in the organisation. (Interview partner 1)

Furthermore, most jurisdictions have not implemented sufficient legal protection for whistleblowers. Ultimately, blowing the whistle requires courage. Therefore, employees need a reason to blow the whistle, as interview partner 7 mentioned:

Yeah, it's often so that whistleblowing needs a justification, you know, a reason why people would report something. Without such a reason they would tend to say, 'Well, why should I get involved, why would I expose myself?'

Likewise, interview partner 3 argued:

Another reason that people were saying they weren't prepared to use whistleblowing was because there was no financial incentive to do so, there's no financial reward.

Finally, interview partner 4 highlighted:

If you do not receive a financial reward or compensation for blowing the whistle, you frankly have no incentive to do so. You're only going to get yourself in trouble.

Five interview partners stated that whistleblowing incentives in the form of bonuses could help overcome barriers to whistleblowing. Interview partner 2 suggested that such bonuses could be based on the fine that the whistleblower helped the company avoid, as is common practice in the US under the Dodd-Frank Act. Interview partner 6 suggested that settlement payments could be shared with the whistleblower, citing a case they had observed in India in which the whistleblower had received a portion of the settlement based on a bounty programme. Here, our interview partners stressed that whistleblowing incentives could be particularly useful in an environment where whistleblowers fear retaliation.

Four of our interview partners identified incentives as particularly helpful in conditions characterised by a lack of confidentiality, arguing that there is a greater need for compliance incentives in an environment where privacy is hard to achieve. Interview partner 4 explained:

But the problem is, if you are working in a very small division and you're providing very specific information and an investigation is launched, it is pretty obvious who blew the whistle. 
Interview partner 9 confirmed that it could be difficult to maintain confidentiality from the perspective of an investigation. Interviewees 2, 3, 4 and 9 stated that they found whistleblowing incentives exceptionally helpful when there is a lack of confidentiality or a fear of retaliation.

On the other hand, taking action against employees for not blowing the whistle could damage the independence of the system:

[...] If you start saying to people, 'Well, we're going to deduct your bonus because you didn't blow the whistle,' I think you would damage the independence of that whistleblowing policy. And I think people would become nervous about using it anyway. (Interview partner 1)

Furthermore, interview partners 2, 6 and 9 argued that employees could be motivated to blow the whistle for personal gain:

Obviously, it creates, or it motivates, people to call but it could go in the wrong direction that people make a business case out of that. (Interview partner 2)

See, when there is a payment mechanism linked to whistleblowing, it can create a problem for organisations in terms of, you know, a lot of times there will be a lot of whistleblowing just because people think they will receive some incentive, but they may not have merit. (Interview partner 6)

In addition, this could lead organisations to become overwhelmed with whistleblowing reports. According to interview partner 9, people might even make false reports to receive a bonus.

Interview partners 5 and 9 stressed how cultural differences can present another barrier to whistleblowing and might need to be incentivised to be overcome: in some countries (e.g. China and Germany), whistleblowing is a form of accusation. The implementation of a no retaliation policy could thus be difficult to achieve in some countries. That other interview partners did not mention this issue could be rooted in them being simply unaware of it. Moreover, respect for top management and senior executives could prevent employees from blowing the whistle. In these situations, incentives could help breach cultural barriers.

Overall, interview partners' suggestions can be assigned to three categories: the importance of effective sanctions; a re-analysis of company culture and the communication of good citizenship; and, lastly, a wide variety of specific preventive steps such as the training of external providers or teaming up with other firms. Interview partners also drew attention to there being no 'one size fits all' solution to lowering the incidence of corruption. 


\section{Table 2 - Scope of applicability, whistleblowing}

\begin{tabular}{|c|c|c|c|}
\hline $\begin{array}{l}\text { Interview } \\
\text { partner }\end{array}$ & Retaliation & $\begin{array}{l}\text { Lack of } \\
\text { confidentiality }\end{array}$ & Cultural differences \\
\hline 1 & $\begin{array}{l}\text { Negative past experiences due to } \\
\text { retaliation } \\
\text { Companies may protect high-profile } \\
\text { employees rather than a whistleblower } \\
\text { Risk of upsetting or having a negative } \\
\text { impact on people to whom the } \\
\text { whistleblower is close } \\
\text { Courage required }\end{array}$ & & \\
\hline 2 & $\begin{array}{l}\text { Lack of tradition and negative } \\
\text { historical experiences } \\
\text { Perception by employees that negative } \\
\text { consequences are only faced by the } \\
\text { whistleblower and not by the } \\
\text { management responsible }\end{array}$ & $\begin{array}{l}\text { Information not } \\
\text { treated } \\
\text { confidentially }\end{array}$ & \\
\hline 3 & Lack of legal protection & $\begin{array}{l}\text { Confidentiality not } \\
\text { protected under } \\
\text { certain jurisdictions }\end{array}$ & \\
\hline 4 & $\begin{array}{l}\text { Fear of severe consequences, e.g. } \\
\text { termination of employment, being } \\
\text { blacklisted in the industry } \\
\text { Negative stigma } \\
\text { Appreciation of and retaliation against } \\
\text { whistleblowers } \\
\text { Whistleblowing hotlines are } \\
\text { promoted, but people who use them } \\
\text { face retaliation. }\end{array}$ & $\begin{array}{l}\text { Confidentiality hard } \\
\text { to achieve }\end{array}$ & \\
\hline 5 & & & $\begin{array}{l}\text { Whistleblowing is not part } \\
\text { of the culture (e.g. in } \\
\text { China) }\end{array}$ \\
\hline 9 & $\begin{array}{l}\text { No retaliation policy hard to achieve } \\
\text { in some countries }\end{array}$ & $\begin{array}{l}\text { Confidentiality hard } \\
\text { to achieve }\end{array}$ & $\begin{array}{l}\text { Respect for higher } \\
\text { management or boss due to } \\
\text { cultural differences }\end{array}$ \\
\hline
\end{tabular}

\section{Discussion}

Our literature review illustrates that corruption is one of the main risks associated with public procurement. The existing risks of corruption are increased significantly in periods of emergency such as during the Covid-19 pandemic which has seen many cases of corruption in the procurement of medical equipment and PPE. Among other factors, organisational weaknesses can facilitate corruption in public procurement. Based on our empirical findings derived from interviews with expert witnesses, 
whistleblowing incentives are proposed as a self-monitoring instrument which can used by companies involved in (emergency) public procurement.

Most firms have some regulatory framework to ensure compliance with existing anti-corruption regulations but it is not guaranteed that these formal rules are applied in their daily operations. When corruption is prevalent in a company, only a change of culture can increase compliance with formal anti-corruption rules. The underlying assumption is that firms benefit from fostering compliance because, when corrupt behaviours are identified and addressed early on, they might - contrary to the situation in Srebrena Malina - be able to mitigate prosecution.

From the company's perspective, whistleblowing is a valuable tool that helps avoid unwanted public attention and sanctions by the authorities. Whistleblowing facilitates companies' self-reporting of corrupt incidences to the authorities which commonly results in milder sanctions. Therefore, companies have an incentive to increase self-monitoring. In addition, whistleblowing can have a preventive effect and facilitate cultural change by demonstrating that corrupt behaviour is not tolerated. On the other hand, regulators are likely to find that firms' increased self-monitoring and reporting can help reduce overall levels of corruption. This assumption could be tested quantitatively in future research.

Whistleblowers render a valuable service by reporting nuisances and corruption. However, the act of whistleblowing is frequently interpreted as a betrayal or is not accepted as a result of cultural aspects while whistleblowers face severe consequences such as the loss of employment or even criminal charges (Teichmann and Falker 2020a). To increase whistleblowing, it must be communicated that eliminating corruption is a first-order goal for the company and that whistleblowing is encouraged (Teichmann and Falker 2020b). In addition, to inspire corrupt government officials to refrain from accepting bribes, it must be communicated that bribery is not tolerated under any circumstances (Teichmann et al. 2020).

It can be observed from media reports concerning Edward Snowden, Chelsea Manning and other whistleblowers that whistleblowing has increased in recent years. In the US, the Dodd-Frank Wall Street Reform and Consumer Protection Act of 2010 (the Dodd-Frank Act) defines incentives, protection and procedures for whistleblowing. Although the US frequently criminalises whistleblowing (as seen in the above cases), internal company bonuses could be modelled in line with the US's DoddFrank Act although they should be smaller, proportionate to the fine the whistleblowing helped to avoid and paid more frequently. Although such bonuses could become expensive for the company, the potential sanctions the company would face subsequent to prosecution would be much higher.

To avoid formal accusations and false reports, whistleblowing bonuses should only be paid when a significant violation has been detected. In such a case, the company could award the whistleblower ten per cent of the fine they helped avoid. Whistleblowing incentive systems can apply to all employees but they do make more sense in some cases than others: employees that do not usually witness or engage in corrupt behaviour due to their position might not be eligible for whistleblowing incentives. 
Opponents of self-monitoring and reporting argue that companies care more about sales than compliance, meaning that they will go to considerable lengths to procure a large government contract. However, there is a high risk that companies becoming involved in public corruption scandals may have to declare bankruptcy at some point due to sanctions and reputational losses. Hence, they do have sound reasons to provide incentives for whistleblowing in the case of serious breaches of compliance because long-term survival is the primary goal of any company.

\section{Conclusion}

The literature review demonstrates that public procurement, which is susceptible to corruption under normal circumstances, becomes even more exposed to the potential risk during emergencies. Effective emergency procurement requires supply chain resilience so that typical demand and supply risks, such as panic buying and the closure of warehouses (Christopher and Peck 2004; Vanpoucke and Ellis 2019), can be avoided. Had the supply chains for medical equipment and PPE been more resilient and prepared for an emergency, governments and private actors would not have found themselves in the position where they believed themselves forced to purchase goods that turn out to be defective and overpriced. The Srebrena Malina corruption case illustrates distinctly the interplay between political instability, weak institutions and decentralisation as factors facilitating corruption in $\mathrm{BiH}$ and other post-transition countries in the western Balkans. The BiH government's decision to simplify public procurement procedures and loosen regulations was likely to be the main factor that allowed Srebrena Malina, a raspberry processing firm, to procure medical equipment despite its lack of professional expertise in the area and its failure to obtain a licence before importing the ventilators.

We can assume that corruption did play some sort of role in Srebrena Malina affair since both Fikret Hodžić, the owner of the company, and Fadil Novalić, the prime minister, had cultivated close relationships with the SDA. Other reasons include that Srebrena Malina was not licensed to trade in medical equipment at the time of procurement and had no relevant expertise. $\mathrm{BiH}$ taxpayer money was therefore wasted when the deficient ventilators were purchased which can be directly attributed to the government's own wilful negligence. BiH has received millions in foreign aid to help it deal with the pandemic. Unfortunately, misappropriations of foreign assistance are not uncommon in the western Balkans but this should not necessarily be the case and it is possible that emergencies can be mitigated effectively. The findings presented here can also be applied to other jurisdictions since the current emergency affects all countries.

This article illustrates that, although it is essential to dedicate as many resources as possible to the fight against emergencies such as Covid-19, compliance and anticorruption measures cannot be neglected during times of crisis. Otherwise, the effects of any efforts undertaken, and the investments made, can be diminished by the inefficient use of resources resulting from corruption and the involvement of organised crime. When shortcuts are taken in public procurement, essential funding is wasted and inappropriate goods and services procured. Most empirical resources suggest anti-corruption measures that are focused on a prevention perspective, e.g. 
policy reforms and increased company surveillance. On the other hand, this study researches the specific steps that companies can themselves take to help undermine corruption in public procurement. Hence, it addresses the organisational factors that facilitate corruption in this area, suggesting the implementation of whistleblowing incentives such as bonuses to help mitigate corruption during emergency situations.

Transparency must be fostered and existing regulations and policies abided by, even in times of crisis, when it comes to public procurement. Even though medical equipment and medicines are desperately needed, governments should not allow firms to take shortcuts or slacken their existing regulations. Instead of simplifying the procurement process, which only makes it more susceptible to corruption, all efforts should be devoted to speeding up current processes and making them more efficient. In this way, companies would gain an incentive to prevent corruption because prosecution and the corresponding sanctions could lead both to reputational losses and indeed to bankruptcy.

\section{References}

2020/C 108 I/01 Guidance from the European Commission on using the public procurement framework in the emergency situation related to the COVID-19 crisis, accessed 19 August 2020 at: https://eur-lex.europa.eu/legal-content/EN/TXT/?uri =uriserv:OJ.CI.2020.18.1.0001.01.ENG.

Appolloni, A. and J. Mushagalusa Nshombo (2014) 'Public procurement and corruption in Africa: a literature review' in: F. Decarolis and M. Frey (eds) Public procurement's place in the world. Central issues in contemporary theory and policy London: Palgrave Macmillan.

Bajari, P and G. Lewis (2011) 'Procurement contracting with time incentives: Theory and evidence' Quarterly Journal of Economics 126: 1173-1211.

Bals, L, H. Schulze, S. Kelly and K. Stek (2019) 'Purchasing and supply management (PSM) competencies: current and future requirements' Journal of Purchasing \& Supply Management 25(5).

Bellavite Pellegrini, C, E. Sironi and B. S. Sergi (2017) 'Stock Returns, Productivity, and Corruption in Eight European Fast-Emerging Markets' Thunderbird International Business Review 59 (1): 15-22.

Bergman, M. A and S. Lundberg (2013) 'Tender evaluation and supplier selection methods in public procurement' Journal of Purchasing \& Supply Management 19: 73-83.

Budak, J and E. Rajh (2013) 'Corruption as an obstacle for doing business in the Western Balkans: A business sector perspective' International Small Business Journal 32(2): 140-157.

Christopher, M and H. Peck (2004) 'Building the resilient supply chain' International Journal of Logistics Management 15(2): 1-13.

Clarke, D, A. Wierzynska, M. DiBiase and A. Timilsina (2020) 'Promoting accountability and transparency during COVID-19' UNDP Blog 9 June 2020 accessed 22 
July 2020 at: https://www.undp.org/content/undp/en/home/blog/2020/promotingaccountability-and-transparency-during-covid-19.html.

Cremer, G (1998) 'On the problem of misuse in emergency aid' The Journal of Humanitarian Assistance accessed 24 August 2020 at: https://sites.tufts.edu/jha/arch ives/131.

Csáki, C and P. Gelléri (2006) 'Conditions and benefits of applying decision technological solutions as a tool to curb corruption within the procurement process: The case of Hungary' Journal of Purchasing \& Supply Management 11: 252-259.

Cuckić, N (2020a) 'Reforming public procurement crucial for fighting corruption in the Western Balkans' European Western Balkans 20 March, accessed 20 July 2020 at: https://europeanwesternbalkans.com/2020/03/20/reforming-public-procu rement-crucial-for-fighting-corruption-in-the-western-balkans/.

Cuckić, N (2020b) 'Ventilators' affair in BiH - Fight against corruption or another political quarrel?' European Western Balkans 5 June accessed 20 July 2020 at: https://europeanwesternbalkans.com/2020/06/05/ventilators-affair-in-bih-fight-ag ainst-corruption-or-another-political-quarrel/.

Djugum, A, E. Bajrovic and A. Heil (2020) 'How did a Bosnian raspberry farm get a state contract to acquire 100 ventilators?' RadioFreeEurope RadioLiberty 5 May, accessed 21 July 2020 at: https://www.rferl.org/a/bosnia-ventilators-scandal-covi d-19-raspberry-farm-multimillion-deal-procurement/30594315.html.

Donahue, A. K and P. G. Joyce (2001) 'A framework for analyzing emergency management with an application to federal budgeting' Public Administration Review 61(6): 728-740.

Duli, I, S. Hoxha and M. Mujovic (2011) Reforms of public procurement in the Western Balkans accessed 20 July 2020 at: http://www.ippa.org/IPPC5/Proceedings/P art7/PAPER7-2.pdf.

Elo, S and H. Kyngäs (2008) 'The qualitative content analysis process' Journal of Advanced Nursing 62(1): 107-115.

European Commission (2020) 'Public procurement' accessed 19 August 2020 at: https://ec.europa.eu/growth/single-market/public-procurement_en.

European Court of Auditors (2018) Public procurement in Western Balkans, synthesis report on the parallel performance audit conducted by the Supreme Audit Institutions of Albania, Bosnia-Herzegovina, the former Yugoslav Republic of Macedonia, Kosovo, Montenegro and Serbia Luxembourg/Stockholm, accessed 21 July 2020 at: https://www.eca.europa.eu/other\%20publications/synthesis_w_b alkans/synthesis_w_balkans_en.pdf.

Evenett, S. J and B. M. Hoekman (2005) 'International cooperation and the reform of public procurement policies' World Bank Policy Research Working Paper 1(1).

Giulietti, C and S. Menafra (2020) 'La strana storia dell'azienda Agricola scelta per fabbricare le mascherine anti coronavirus' [in Italian] Open $18 \mathrm{March}$, accessed 
22 July 2020 at: https://www.open.online/2020/03/18/la-strana-storia-dell-aziend a-agricola-scelta-per-fabbricare-le-mascherine-anti-coronavirus/.

Gläser, J and G. Laudel (2010) Experteninterviews und qualitative Inhaltsanalyse: als Instrumente rekonstruierender Untersuchungen [in German], Wiesbaden: VS Verlag für Sozialwissenschaften.

Hsieh, H. F and S. E. Shannon (2005) 'Three approaches to qualitative content analysis’ Qualitative Health Research 15(9): 1277-1288.

Human Rights Council (2020) Connecting the business and human rights and the anti-corruption agendas Report of the Working Group on the issue of human rights and transnational corporations and other business enterprises, prepared pursuant to Human Rights Council resolutions 17/4 and 35/7, 15 June - 3 July 2020, accessed 20 July 2020 at: https://www.ohchr.org/Documents/Issues/Busine ss/A_HRC_44_43_AdvanceEditedVersion.pdf.

International Group for Anti-Corruption Coordination (2005) Report on the Seventh Meeting of the International Group for Anti-Corruption Coordination accessed 24 August 2020 at: https://www.unodc.org/pdf/corruption/7th_interagency_meeti ng.pdf.

Karjalainen, K, K. Kemppainen and E. M. van Raaj (2009) 'Non-compliant work behaviour in purchasing: an exploration of reasons behind maverick buying' Journal of Business Ethics 85(2): 245-261.

Kauppi, K and E. M. van Raaj (2015) 'Opportunism and honest incompetence Seeking explanations for noncompliance in public procurement' Journal of Public Administration Research and Theory 25(3): 953-979.

Kähkönen, A. K and K. Lintukangas (2013) 'Supply management as a value creating element in a firm' International Journal of Value Chain Management 6(4).

Knight, L, J. Meehan, E. Tapinos, L. Menzies and A. Pfeiffer (2020) 'Researching the future of purchasing and supply management: the purpose and potential of scenarios' Journal of Purchasing and Supply Management 26(3).

Lindskog, H, S. Brege and P. O. Brehmer (2010) 'Corruption in public procurement and private sector purchasing' Organisational Transformation and Social Chance 7(1): 167-188.

Ljubas, Z (2020) 'PM of one of Bosnia's regions detained over ventilator procurement' OCCRP 29 May accessed 20 July 2020 at: https:/www.occrp.org/en/daily/ 12442-pm-of-one-of-bosnia-s-regions-detained-over-ventilator-procurement.

Manea, I. L and I. A. Popa (2010) 'Risk Management in public procurement process' Studies and Scientific Researches - Economic Edition 15.

Marquette, H (2020) 'Fighting corruption during the coronavirus' Global Initiative Against Transnational Organized Crime 3 June, accessed 22 July 2020 at: https:// globalinitiative.net/corruption-coronavirus/. 
Mayring, P (2010) Qualitative Inhaltsanalyse: Grundlagen und Techniken [in German], Weinheim: Beltz.

Mrčela, M (2020) Corruption risks and useful legal references in the context of COVID-19 GRECO, 15 April, Strasbourg, accessed 22 July 2020 at: https://rm.co e.int/corruption-risks-and-useful-legal-references-in-the-context-of-covid-1/1680 $9 \mathrm{e} 33 \mathrm{e} 1$.

N1 Sarajevo (2020) 'Sarajevo prosecutors probe tender for procurement of ventilators from China' 27 April, accessed 20 July 2020 at: http://ba.n1 info.com/English/NEWS/a428951/Sarajevo-Prosecutors-probe-tender-for-procurement-of-vent ilators-from-China.html.

Patrucco, A. S, D. Luzzini, S. Ronchi, M. Essig, M. Amann and A. H. Glas (2017) 'Designing a public procurement strategy: lessons from local government' Public Money \& Management 37(4): 269-276.

Pekmez, I and A. Husaric (2021) 'In Bosnia ventilator scandal, manufacturer's warnings unheard or unheeded' Balkan Insight 18 October, accessed 25 November 2021 at: https://balkaninsight.com/2021/10/18/in-bosnia-ventilator-scandal-manu facturers-warnings-unheard-or-unheeded/.

Potoski, M (2008) 'State and local government procurement and the winter commission’ Public Administration Review 68: 58-69.

Qerimi, Q and B. S. Sergi (2007) 'Fighting corruption and organised crime as a means of socio-economic development in south-east Europe' South-East Europe Review for Labour and Social Affairs 10(2): 81-94.

Qerimi, Q and B. S. Sergi (2012) 'The boundaries of a neglected relationship: Corruption and economic freedom. The case of the Western Balkans' Problems of Economic Transition 55(2): 68-97.

Qerimi, Q and B. S. Sergi (2021) 'Let's Lessen Conditionality in Times of Force Majeure Events. The Archaic Righteousness of the Policy of Conditionality of International Institutions Amid COVID-19' Research in International Business and Finance 58, December.

Sauer, P, E. Gershkovich and J. Cordell (2020) 'Exclusive: Rich Russians are hoarding ventilators to protect themselves against the coronavirus' The Moscow Times 21 March accessed 22 July 2020 at: https://www.themoscowtimes.com/2020/03/2 1 /exclusive-rich-russians-are-hoarding-ventilators-to-protect-themselves-againstthe-coronavirus-a69703.

Schultz, J and T. Søreide (2008) 'Corruption in emergency procurement' Disasters 32(4): 516-536.

Simić, J (2020) 'Serbia turns to China due to "lack of EU solidarity" on coronavirus' Euractiv 18 March accessed 22 July 2020 at: https://www.euractiv.com/section/c hina/news/serbia-turns-to-china-due-to-lack-of-eu-solidarity-on-coronavirus/. 
Simon, R and G. Aalbers (2020) The 2020 Capacity to Combat Corruption (CCC) Index accessed 20 July 2020 at: https://www.as-coa.org/sites/default/files/archive 12020_CCC_Report.pdf.

Slijepčević, S, J. Budak and E. Rajh (2015) Challenging competition at public procurement markets: Are SMEs too big to fail? The case of BiH and Croatia Institute of Economics Zagreb Working Paper, accessed 21 July 2020 at: https://www. eizg.hr/UserDocsImages/publikacije/serijske-publikacije/radni-materijali/Challen ging_Competition_at_Public_Procurement_Markets_Are_SMEs_Too_Big_to_Fa il-The\%20Case_of_BiH_and_Croatia.pdf.

Søreide, T (2002) 'Corruption in public procurement: causes, consequences and cures' Chr. Michelsen Institute CMI Report R 2002 Bergen, accessed 24 August 2020 at: https:/www.cmi.no/publications/843-corruption-in-public-procurementcauses.

Steingrüber, S, M. Kirya, D. Jackson and S. Mullard (2020) Corruption in the time of COVID-19: A double-threat for low income countries U4 Anti-Corruption Resource Centre Brief, accessed 21 July 2020 at: https://www.u4.no/publications/co rruption-in-the-time-of-covid-19-a-double-threat-for-low-income-countries.

Stilger, P. S, J. Siderius and E. M. van Raaj (2017) 'A comparative study of formulas for choosing the economically most advantageous tender' Journal of Public Procurement 17(1): 88-214.

Teichmann, F (2017) Anti-bribery compliance incentives Kassel: Kassel University Press.

Teichmann, F and M. C. Falker (2020a) 'Compliance Incentives, Whistleblowing, and the Payment of Rewards for Information' in: B. S. Sergi and E. G. Popkova (eds) Artificial Intelligence: Anthropogenic Nature Vs. Social Origin Zürich/ Lausanne: Springer, pp. 490-499.

Teichmann, F. and M. C. Falker (2020b) 'Whistleblowing Incentives' Journal of Financial Crime 28(2): 394-405.

Teichmann, F, M. C. Falker and B. S. Sergi (2020) 'Gaming Environmental Governance? Bribery, Abuse of Subsidies, and Corruption in European Union Programs' Energy Research and Social Science 66.

Teichmann, F and B. S. Sergi (2018) Compliance in Multinational Corporations: Business Risks in Bribery, Money Laundering, Terrorism Financing and Sanctions London: Emerald.

Transparency International Bosnia and Herzegovina (2001) The international community is not immune to the corruption plague either Banja Luka, accessed 20 July 2020 at: https://ti-bih.org/wp-content/uploads/Documents/izvjestaji/e/Corrup tion \%20in\%20IC.\%20report.pdf.

UNODC (2020) COVID-19-related trafficking of medical products as a threat to public health Vienna, accessed 20 July 2020 at: https://www.unodc.org/docu- 
ments/data-and-analysis/covid/COVID-19_research_brief_trafficking_medical_p roducts.pdf.

van Hoek, R (2020) 'Research opportunities for a more resilient post-COVID-19 supply chain - closing the gap between research findings and industry practice' International Journal of Operations \& Production 40(4): 341-355.

Vanpoucke, E and S. Ellis (2019) 'Building supply-side-resilience - a behavioural view' International Journal of Operations and Production Management 40(1): 11-33.

Vecchi, V and N. Cusumano (2020) 'COVID-19: lessons from Italy on public-private healthcare procurement' World Economic Forum, 12 May, accessed 19 August 2020 at: https://www.weforum.org/agenda/2020/05/covid-italy-public-private-pr ocurement/.

Verdeaux, J. J (2003) 'Public procurement in the European Union and the United States: a comparative study' Public Contract Law Journal 32: 713-738.

Zuvela, M, D. Sito-Sucic and M. Heinrich (2020) 'Bosnian official suspended amid probe into import of defective ventilators' swissinfo, 12 May, accessed 20 July 2020 at: https://www.reuters.com/article/us-health-coronavirus-bosnia-ventilators-idUSKBN22O26R.

Fabian Teichmann is Managing Partner at Teichmann International (Schweiz) AG, Dufourstrasse 124, 9000 ST. GALLEN, Switzerland. e-mail: info@teichmann-law .ch.

Marie-Christin Falker works on compliance issues for Teichmann International, (Schweiz) AG, Dufourstrasse 124, 9000 ST. GALLEN, Switzerland. e-mail: info@te ichmann-law.ch. 
